\title{
Science-Literacy Integration: Equity and Learning in First- Grade, Urban Instructional Contexts
}

\author{
Angela J. Stefanski \\ Ball State University \\ Nicole M. Martin \\ Ball State University \\ Melinda A. Zurcher \\ Ball State University
}

Previous research demonstrates that integration of science and literacy instruction in primary grades has positive outcomes for students' science and literacy development. However, variations in how science and literacy are enacted suggest integration may not be sufficient to meet the literacy and science needs of all students in an equitable manner. The purpose of this study was to examine two first-grade teachers' science integration during literacy instruction in one high- and one low-income school context within one urban district. Analysis of field notes, transcripts of lessons, and interviews revealed that expectations to integrate science during time set aside for literacy instruction without consideration of contextual factors perpetuated and concealed ongoing inequities in science education for students from the lowest income school. Further, this study adds to evidence from prior studies demonstrating that reading of science-related texts alone, as a substitute for instruction in science as a discipline, does not provide students with the resources needed to learn to think, talk, and act as scientists. Findings from this study require researchers and policy-makers to address the context-specific factors that shape instructional contexts in ways that limit or expand the potential of integrated science-literacy instruction in urban schools.

Keywords: science-literacy integration, instructional contexts, equity, first grade, urban schools

\section{Introduction}

“Science? We don’t do science here!” (First-grader, PS.2)

As teacher educators specializing in literacy education, we frequent primary-grade classrooms in a variety of contexts. During these visits, we have noted that science was not consistently posted as part of the daily schedule, particularly in the low-socioeconomic-status (SES) schools, despite research indicating that all children are capable of and benefit from learning science (Bousselot, 2018; Cervetti, Barber, Dorph, Pearson, \& Goldschmidt, 2012; Ippolito, Condie, Dobbs, CharnerLaird, \& Blanchette, 2017; Shanahan \& Shanahan, 2014). Also, the Next Generation Science Standards expect even young children to learn to conduct investigations, analyze and interpret data, construct explanations, design solutions, and develop understandings of concepts and relationships between science concepts (National Research Council, 2013, p. 9).

Teachers and administrators explained that, rather than excluding science altogether, they "integrated science" into literacy instruction. This practice is not new. Since the passage of No Child Left Behind (2002), educators frequently frame integrated instruction as a solution to time 
constraints placed on subjects not weighted as heavily on high-stakes tests (Diamond \& Spillane, 2004; Jones \& Swanson, 2009; Lee, Deaktor, Hart, Cuevas, \& Enders, 2005; Matuk, Hurwich, Spiegel, \& Diamond, 2019; Poldberg, Trainin, \& Andrzejczak, 2013).

However, in the classrooms we frequent, a focus on reading and math seemed to take precedence over integrating science into literacy instruction, particularly in low-SES schools. Prior research has attributed this focus to contextual factors such as pressures from high-stakes testing (Diamond \& Spillane, 2004; Dooley \& Assaf, 2009; Hayes, 2015) and deficit perspectives of students in poverty (Gorski, 2008; Ladson-Billings, 2014; Mangiante, 2018; Pitts, 2011). Deficit perspectives assume achievement gaps between poor and affluent students exist in the "minds, bodies, cultures, and communities" of students in poverty (Dudley-Marling, 2015, p. 2; see also Anyon, 1981; Brantlinger, 2003; Keefer, 2017; Ladson-Billings, 2014) resulting in lower expectations and limited access to quality science instruction (A. C. Barton \& Yang, 2000; Diamond \& Spillane, 2004; Mangiante, 2018; Southerland, Gallard, \& Callihan, 2011; Wright \& Gotwals, 2017). Thus, curriculum functions as a form of power in which some students have opportunities that others do not (Delpit, 1988).

Recognizing that inequalities in science instruction exist for these and other reasons (Hayes, 2015; Kucsera, Siegel-Hawley, \& Orfield, 2014; Marshall, 2018; Merritt, Chiu, Peters-Burton, \& Bell, 2018; Smith, Trygstad, \& Banilower, 2016; Wright \& Gotwals, 2017), we questioned when and in what ways students were learning science during literacy instruction. We conducted a cross-case analysis in two urban first-grade classrooms, representing one low- and one high-SES school within one school district. Our study extends prior research by focusing on how the instructional contexts of integrated instruction taught during time set aside for literacy and in the absence of researchers' direct intervention influences first-graders' opportunities for science learning.

\section{Literature Review}

Integration of science and literacy instruction involves simultaneously attending to primary students' science and literacy learning. In this study, we use the term science (rather than STEM [i.e., science, technology, engineering, and mathematics] or STEAM [i.e., science, technology, engineering, art, and mathematics]) to reflect teacher-participants' and scholars' framing of integrated science-literacy instruction (e.g. Cervetti, Pearson, Bravo, \& Barber, 2005; Hong, Moran, Jennings, Robertson, \& Fisher, 2019; Robertson \& Moran, 2019). Literacy, in our definition, extends beyond a discrete set of skills and concepts to include multiple literacies, some of which may be valued highly, whereas others are rendered invisible within particular instructional contexts (D. Barton, 2007; Hong et al., 2019; Ives, 2011; Sang, 2017; Sørvik, Blikstad-Balas, \& Ødegaard, 2014). Students learn what and whose literacies count in science and literacy as teachers integrate instruction in particular ways.

Researchers have convincingly argued that science and literacy are inseparable and symbiotic (e.g., Cervetti et al., 2012; Fang \& Wei, 2010; Hong et al., 2019). As Fang and Wei (2010) noted, “...reading is inextricably tied to the very nature and fabric of science. It is seen as a powerful vehicle for engaging students' minds, fostering the construction of conceptual understanding, supporting inquiry, and cultivating scientific habits of mind" (p. 263).

Science inquiry and literacy share similar processes that may be leveraged to reinforce one another (Cervetti et al., 2012). Additionally, when students have opportunities to learn science along with literacy, they develop essential discipline-specific vocabulary and language for future academic success (Gee, 2004; Hong et al., 2019; Nagy \& Townsend, 2012; Tolbert, Stoddart, Lyon, \& Solis, 2014). When integrated instruction has been used to enhance, not replace, science inquiry, students have displayed knowledge and process-oriented gains in science and literacy (Casey, Mireles, Viloria, 
\& Garza, 2018; Odegaard, Haug, Mork, \& Sorvik, 2015; Pappas, Varelas, Kokkino Patton, Ye, \& Ortiz, 2012; Pearson, Moje, \& Greenleaf, 2010).

The shared processes and benefits may explain why educators and researchers look to integrated science-literacy instruction as a promising practice in urban schools. However, inequities in science instruction attributed to factors such as time constraints on science instruction, accountability pressures, and teachers' beliefs, as well as persistent science achievement gaps between low- and high-SES students, highlight the need for more attention to science instruction in the primary grades (Curran, 2017; Hayes, 2015; Mangiante, 2018; Morgan, Farkas, Hillemeier, \& Maczuga, 2016). Reduced access to science affects students' language development, future school success, and visions of themselves in science-related careers (Maltese \& Tai, 2010; Xu, Coats, \& Davidson, 2012). Nelson and Norton-Meier (2009) contended that reducing students' access to subjects "limits the ways in which they will come to know, understand, and communicate about a variety of content areas" (p. 1). Importantly, researchers have concluded that waiting to teach science until the intermediate grades is too late and contributes to the persistent achievement gaps for low-SES students (Ippolito et al., 2017; Morgan et al., 2016; National Research Council, 2013).

Prior research underscores the potential benefits of integrated science-literacy instruction. Researchers have found positive, significant outcomes in primary students' identification as scientists, understanding of the nature of science, and science knowledge through programs such as the Scientific Literacy Project and Seeds of Science-Roots of Reading (e.g., Ippolito et al., 2017; Girod \& Twyman, 2009; Mantzicopoulos, Patrick, \& Samarapungavan, 2009). Also, previous studies have demonstrated that science can be added to literacy instruction without sacrificing students' literacy learning (e.g., Cervetti et al., 2012; Vitale \& Romance, 2012).

However, a greater understanding of how science is integrated during time set aside for literacy and in the absence of researchers' direct intervention in urban first-grade classrooms is needed (Douville, Pugalee, \& Wallace, 2003; Nollmeyer, Kelting-Gibson, \& Graves, 2016). Approaches to integration have included (a) thematic connections between science and literacy, (b) the use of one discipline to bolster the other, and (c) an equal focus on learning in both disciplines (Cervetti et al., 2012). In addition, some approaches have privileged "hands-on" science inquiry, but other approaches have consisted of students' reading of informational text (Mantzicopoulos et al., 2009; Pappas et al., 2012). These varied approaches to integration offer very different learning opportunities, sometimes reducing students' access to science curricula, scientific development, and future science achievement (Lindquist \& Neal, 2016; Maltese \& Tai, 2010; Nelson \& Norton-Meier, 2009; Tolbert et al., 2014).

Educators have voiced concerns about the limits of integrated science-literacy instruction. Dickinson and Young (1998) once argued, "Language arts and science are different disciplines. While instruction in one can complement the other, the expectation that instruction in one can substitute for separate instruction in both is mistaken" (p. 336). The two disciplines include shared processes but also unshared, discipline-specific processes (Gee, 2001). Previous studies have demonstrated that focusing solely on reading informational text during integration has unintended consequences on students' scientific development (Cervetti et al., 2005; Howes, Lim, \& Campos, 2008). Students may concentrate on factual knowledge but (a) misunderstand how science knowledge is constructed, (b) ignore applications of science in the real world (cf., National Research Council, 2012, p. 43), (c) develop misunderstandings about the nature of science, and (d) fail to envision themselves as scientists.

The concerns are particularly relevant for first-graders. To learn to read and write, first-grade students need to develop knowledge and skills outside the purview of science learning, such as knowledge of how sounds are mapped onto print and how to read and write different kinds of texts 
for a variety of meaningful purposes (Ehri \& McCormick, 2013; Pressley \& Allington, 2015; PurcellGates, Duke, \& Martineau, 2007). Also, case studies and examinations of teachers' uses of informational text suggest that reading of the texts in first-grade classrooms is limited and insufficient to address the objectives of learning science (Cervetti et al., 2005; Duke, 2000a; Howes et al., 2008; Pappas et al., 2012).

This is not to say that the use of informational text is not beneficial. Previous studies have demonstrated teachers' uses of informational text can support first-grade students' science development. For example, Pappas and colleagues (2012) conducted a case study of a first-grade teacher who incorporated "dialogically-oriented" read-aloud sessions of informational text and handson inquiry in a culturally and linguistically diverse setting and found that the texts and talk served as "mediators" for students' development of scientific language and reasoning.

First-grade teachers in lower SES schools may be especially vulnerable to privileging literacy over science learning (e.g., Duke, 2000a; Howes et al., 2008). For example, Howes et al. (2008) found that the first-grade teacher in their study "fit science into an already crowded day" (p. 209) through a text-based unit of study. Students used informational text to conduct research but were not provided opportunities for firsthand investigations. Researchers pointed out that the unit enabled students to develop skills related to reading and learning from text but not developing understanding from "evidence gathered directly from the world through one's senses" (p. 210). Also, in a study of 20 firstgrade classrooms, Duke (2000a) concluded that students spent $3.6 \mathrm{~min}$ per day on average with informational text. Only a portion of these texts focused on science. In the lower SES schools, students spent from 0 to 1.9 min per day in informational texts and had fewer choices for their reading and writing (Duke, 2000b).

In summary, prior research on integrated science-literacy instruction in urban first-grade classrooms suggests (a) a variety of approaches exist, (b) integration can support students' achievement, and (c) integration may not sufficiently address students' learning about scientific inquiry. Studies also highlighted students' limited and unequal access to quality science instruction and exposure to science-related concepts through informational texts in low-SES schools. The available evidence mirrors trends found in science instruction and raises serious concerns about the capacity for integrated science-literacy instruction to offer equitable science learning opportunities for first-grade students in urban classrooms.

\section{Theoretical Framework}

We draw on sociocultural perspectives which view science instruction and development as inherently social processes shaped by local instructional contexts. In this view, the contexts directly and indirectly influence instruction and development by shaping the nature and extent of students' scientific experiences; their learning to talk, to think, and to act like scientists; and their gaining of future "access to social goods (money, power, status)" (Gee, 1991, p. 5) in scientific communities.

During science and integrated science-literacy instruction, students create science identity kits (Gee, 2001). These kits include scientific discourses, or "ways of combining and coordinating words, deeds, thoughts, values, bodies, objects, tools, and technologies, and other people (at the appropriate times and places) so as to enact and recognize specific socially situated identities and activities" (Gee, 2001, p. 721). These kits contain devices such as actions, attitudes, and objects used to identify individuals as members of scientific communities. Through participation in classroom interactions, students construct situated understandings of what science, scientist, learning and doing science, and being a scientist means which influence the knowledge and skills available for their science identity kits. For example, images of mature, Caucasian men wearing lab coats and safety glasses accompanied by the caption "scientist" may be used during instruction, and students may be told that the information 
they are reading came from scientists. They may construe (a) only mature, Caucasian men are scientists; (b) science involves knowing information; and (c) learning entails coming to know what the scientists know. Students may add the text's information to their identity kits but may not realize that they can know and produce scientific knowledge.

As students develop science identity kits, their participation in classroom interactions is shaped by instructional contexts. The contexts make available material and social resources such as shared language, roles, assumptions, and worldviews (cf. Gee, 1991; Smith et al., 2016; Wenger, 1998). These resources establish classroom talk practices and instructional routines that allow compatible actions, talk patterns, and uses of resources but discourage incompatible ones (e.g., Gee, 2004). The practices and routines also convey meanings which are subsequently included in students' situated understandings and identity kits.

Moreover, instructional contexts are uniquely regulated by (a) state and district policies, (b) schoolwide factors such as curricular mandates, and (c) classroom literacy events. These factors influence elements such as time allotted for instruction, daily routines, resource usage, and social interactions (e.g., Keys \& Bryan, 2001; Sunderman, 2008). The resulting differences in contexts means that what counts as "science," how much attention is devoted to science, and what and how science is taught differs by classroom. Consequently, students' participation in instruction and creation of science identity kits will differ by classroom.

\section{Study Purpose}

We conducted a cross-case analysis of two first-grade classrooms in one urban school district (Merriam \& Tisdell, 2016). In contrast to prior research describing specific approaches to, and outcomes of, integrated instruction, our goal was to understand how integrated science-literacy instruction was being enacted during time set aside for literacy instruction in the absence of researchers' direct intervention in instructional contexts serving low- and high-SES students. The term literacies includes social and cultural uses of language that define and are defined by instructional contexts (Bloome et al., 2008). We used a sociolinguistic approach to analyze interactional and contextual factors in concert with language use (Erickson, 2004; Lakoff, 2015, p. 305). Our research questions were as follows:

Research Question 1: In what ways do teachers in two urban first-grade classrooms integrate science during time set aside for literacy instruction?

Research Question 2: How do school and classroom factors influence the teachers' integration of science during literacy instruction and first-grade students' opportunities for science learning?

\section{Method}

We selected two first-grade classrooms from a large urban district in the Midwest (all names are pseudonyms). Classrooms were purposefully selected from one high- and one low-SES school (based on free and reduced lunch designation). Public School 4 (i.e., PS.4) represented one of the district's highest SES schools, with a poverty rate of $45 \%$, and $62 \%$ of the student body was identified as students of color. PS. 2 represented a hypersegregated school context, in which $87 \%$ of the students received free or reduced lunch and $95 \%$ percent were identified as students of color. It is important to note implications of the intersectionality of race and SES (American Psychological Association, 2019). Although our focal schools were selected on the basis of SES, the demographics varied significantly between the two schools as they did between other schools in the district-reflective of the segregated nature of the city and the processes by which the district determined school boundaries. 
Principals from each school recommended one teacher with at least 7 years of experience whom they considered highly successful based on students' achievement and their own observations. These teachers served as reputational cases, to consider the experiences and instruction of an expert in the field (Savin-Baden \& Major, 2013). Ultimately, our goal was to understand how teachers integrated science instruction during time set aside for literacy. An ineffective teacher might have revealed needs for improvement in this area but not represented the strongest case for analysis. Thus, principals recommended Ms. Burkhart from PS.2 with 16 years of teaching experience and Ms. Eldridge from PS.4 with 14 years of experience teaching. Both teachers identified as White (nonHispanic) women from middle-SES backgrounds.

\section{Data Collection}

Over a period of 5 months, we collected multiple forms of data to confirm and extend findings (Flick, 2009 , p. 381). In each classroom, we conducted 10 nonparticipatory observations during time set aside for literacy and one full-day observation (over $50 \mathrm{hr}$ total). An educational science consultant, who observed in each classroom at least once, provided expert insights through extensive fieldnotes and regular meetings with researchers. The first two authors and two research assistants visited the classrooms on alternating days throughout the semester. On initial visits to each classroom, the first author conducted field observations with the other researchers to ensure consistency in how data were collected. Fieldnotes described classroom literacy events, interactions, text use, and resource availability.

We audio-recorded classroom literacy events, had them transcribed verbatim by a research assistant, and then checked them for accuracy. To document the availability of material resources and their arrangement in the physical environment, photographs of the classroom literacy environment were taken. To explore influences on the integration of science during literacy instruction, semistructured interviews were conducted with the teachers at the conclusion of the study. The interview protocol consisted of questions related to science-literacy instruction, use of texts, allocation of instructional time, and professional development.

\section{Data Analysis}

Analysis occurred in several phases. First, to consider differences in scheduling, teaching routines, and resources available to students, we developed descriptive memos for each classroom (Merriam \& Tisdell, 2016). Next, instances of science-literacy integration during time set aside for literacy instruction were isolated in fieldnotes. We analyzed the transcripts of these events to make visible the interactional patterns and language use that shaped what and whose science-related literacies were privileged in each classroom (Bloome et al., 2008). The initial coding scheme for analysis was developed through independently open coding transcripts and then coming together to refine codes and relate our developing scheme to prior research on classroom discourse (e.g., Cazden, 2001; Nystrand, 1997; Pappas et al., 2012).

After refining the coding scheme, we returned to coding and looking for relationships between the codes. To develop and check for salient themes, we moved among independent coding, descriptive memos, and raw data. We also searched for nonconforming cases to guard against potential bias. For example, when the pattern in PS.2 developed of Ms. Burkhart's emphasizing word knowledge, we searched for instances in which she focused more on science concepts. Through these discussions, we constructed themes within and then across cases (Charmaz, 2006; Merriam \& Tisdell, 2016). The triangulation of data sources, extended time in the classrooms, and consultation with a science expert added credibility to our analysis. 


\section{Findings}

Through our analysis, we constructed four themes. The first two themes describe factors that shaped the teachers' integration of science and literacy instruction during time set aside for literacy, including time allotted for instruction and the availability of science-related texts. The final two themes highlight what science, scientist, learning and doing science, and being a scientist meant in each context. These themes include instructional uses of science-related texts and students' participation in science learning.

\section{Time for Science Instruction}

Time for science instruction reflected the first, most obvious inequity in students' experiences. The daily schedule for PS.2 included 140 min of literacy instruction with no time set aside for science. During our introductory visit, we explained to the class that we wanted to study how they learn science and literacy. With that, students looked confused. One student spoke up, stating definitively, "Science? We don't do science here!"

Ms. Burkhart (PS.2) confirmed this in her interview when she whispered that she placed little emphasis on science instruction. She explained that pressures from the district, mandated tests, and her administrator's emphasis on test scores required that she teach the "basics in reading and math-decoding words..." As a result, she placed emphasis on "things that were easily scorable, such as DIBELS [Dynamic Indicators of Basic Early Literacy Skills, an assessment they used to measure students' accurate word reading and reading rate]," leaving no time for science instruction.

In contrast, PS.4 included approximately 95 min of daily literacy instruction, with an additional 75 min devoted to science inquiry. Ms. Eldridge experienced more freedom to develop the science curriculum with her colleagues. She described how this process worked:

The first thing we do is look at standards, look at the unit, look at the bits and pieces of what we're going to teach. Like we looked and said we have this [name of science kits]. Then we pull from other curriculums what we want to do, then we pick from our texts we havegathering all these pieces... Choosing based on what the science standards connect to... Most of what I do isn't measurable, and that's okay. That joy, that spark, the collective love for what we're learning.

Ms. Eldridge explained that she changed the schedule depending upon students' needs and school events, such as building a community garden (one of two science projects underway during our observations). She shared that it was difficult to calculate the time spent teaching science, because she integrated it throughout the day.

In sum, differences in time for science instruction combined with differences in curricula provided strikingly different instructional contexts for science learning. Ms. Burkhart (PS.2) expressed that pressures from high-stakes testing influenced everything, including the schedule and what she taught. In contrast, Ms. Eldridge (PS.4) described having flexibility to schedule and design curricula focused on college-ready standards, her students, and a love for learning.

\section{Availability of Science-Related Texts}

Field notes and photographs provided evidence that both teachers made similar numbers of sciencerelated texts available. However, the types of texts, display of texts, and daily instructional routines differed. School and state policies shaped how these texts were made available to students for science learning. 
Although PS.2 had science-related trade books available in the reading corner, they were not prominently displayed or used during our observations. Students' encounters with science-related texts occurred during small-group, guided reading lessons. Ms. Burkhart met one to four times weekly with each group. During these 15- to 20-min lessons, Ms. Burkhart used leveled (and primarily informational) texts from the mandated curriculum.

In contrast, in PS.4, Ms. Eldridge used the schoolwide inquiry approach and a reading and writing workshop approach in which students read and wrote in a variety of genres. She made sciencerelated texts available through book talks, mini-lessons about how to read informational text, and read-aloud sessions of student-created books. She displayed easy-to-access baskets of texts and invited students to browse through and read texts of their choice with peers. In her interview, Ms. Eldridge emphasized that she read aloud informational text at different reading levels so students could see her reading books like theirs.

In these instructional contexts, similar numbers of science-related texts did not equate to equal availability. Although the texts were available in PS.2, students did not have opportunities or encouragement to read them on their own. Instead, they read leveled texts from the reading program. In PS.4, reading the available science-related texts was part of classroom life-something they talked about and did together. The number of science-related texts in each classroom was not as important as how they were made available in each instructional context.

\section{Instructional Uses of Science-Related Texts}

The analysis of classroom discourse suggested that teachers' instructional uses of science-related texts influenced students' opportunities to develop conceptual understandings related to science. In PS.2, Ms. Burkhart's text use focused on reading for accuracy and word knowledge, whereas in PS.4, Ms. Eldridge emphasized students' comprehension of texts' ideas and scientific knowledge.

\section{PS.2: Reading for Accuracy and Word Knowledge}

The following two excerpts from Ms. Burkhart's guided reading lessons in PS.2 illustrate her instructional use of texts. In the first excerpt, students were rereading a text which compared the characteristics and life cycles of pumpkins and marigolds (Marzollo, 1996). Ms. Burkhart provided reminders about how to sound out words, checked for understanding of the words, and corrected students:

Daniel: my e-dge

Ms. Burkhart: remember, long I

Daniel: I

Ms. Burkhart: I. Died.

Daniel: I'm ro-

Ms. Burkhart: Round.

Daniel: and green.

Ms. Burkhart: Good. What's round and green? Show me in the picture what matches that.

Daniel: [points to page]

Ms. Burkhart: That's not round; this is round and green! What is that?

When they came to the end of the book, Ms. Burkhart instructed, "Go back and look at some of the words we need to know in this." Students turned to different pages and discussed selected words. In this excerpt, the teacher's instructional use of texts highlighted the meanings of words in context, but intentional instruction related to science concepts was notably absent. 
In the second excerpt, Ms. Burkhart guided students as they read a text about insects. Students attempted to identify the insects pictured on the page, use precise scientific language, and wrestle with concepts related to the food chain (what eats what):

James: What kind of bee is this?

Michael: You should have said, "What kind of insect is this?"

James: "What you can see"-this is a spider.

Brandon: No, that's a dragonfly.

Elias: That's disgusting.

James: You know these bugs, you know these bugs, dude, these bugs, this bug eats every single other bug.

Noah: But what about this bug versus praying mantis?

Ms. Burkhart continually redirected students, saying "Let's break this up"; "Wait a minute, you've got to read this page"; and "Oh, I love how you're breaking it up." Their talk was taken up, or sanctioned, only near the end of the lesson when it aligned with her focus on texts' words:

Ms. Burkhart: Okay—shh—we had an idea about what-

James: Insects?

Ms. Burkhart: Shh. About what insects have, okay? Page 6 is all about what insects have. The parts of their...?

Students: [chorus] Body.

Ms. Burkhart: Body. What it takes to be an insect, okay? Let's take a look at this word. Now we just worked on this word.

Michael: Antenna!

As this lesson illustrates, Ms. Burkhart took up students talk only when it related to words in the text. Their student-initiated attempts to understand science concepts were ignored or treated as off task behaviors.

PS.4: Reading for texts' ideas and science concepts. The following two excerpts from Ms. Eldridge's whole-group lessons illustrate how her instructional use of texts emphasized students' prior classroom and personal experiences to support understanding of texts' ideas and scientific concepts.

The first excerpt, taken from fieldnotes, occurred as students returned to the carpet for a class discussion after reading self-selected texts. Ms. Eldridge asked a student to share a discovery he made while reading:

Teacher asks the student to get the book that he had when he noticed a connection to what they'd been discussing in science. Teacher asked him to read the part to the rest of the class. "How does that connect to what we've been learning?" Teacher continues the discussion of solids, liquids, gases. "Can something be a liquid and a solid at the same time?" Students talked about the properties of all three states and even talked about plasma! Teacher reads a book (Solid or Liquid) and students identify the material as a solid, liquid, or gas. Properties are discussed (appropriate vocabulary) with examples.

In this excerpt, students used texts to connect and construct their knowledge of the states of matter. Also, the teacher's use of text occurred in the context of ongoing inquiry, including hands-on explorations, offering opportunities for students to read for meaningful purposes as they accessed and applied previously-learned and new ideas about solids, liquids, and gases.

In the second excerpt, Ms. Eldridge led students in a whole-class discussion prior to reading a text about the states of matter. In this instructional context, the teacher drew students' attention to the 
use of words and scientific vocabulary as tools to jointly construct understanding and to make connections with their prior hands-on experience:

Ms. Eldridge: Oh, you can break solids. Each piece holds its shape. So a solid does hold its shape. It is; you know what? The word that I would use to describe this is ceramic or maybe clay. And if you remember, clay is a form of [pauses for students to think] rock. Remember we learned that!

Caleb: Clay is solid and when you warm it up it gets hard!

Emma: You can make clay!

Ms. Eldridge: You're right. You're right.

Isaac: You can turn clay into cups

Ms. Eldridge: Isn't that interesting that clay starts off soft and when you add heat...Wait, wait. Hold on. Go ahead, finish your sentence.

Keith: Um when you add heat to it, it gets warm. It gets hard.

In the excerpt, Ms. Eldridge highlighted students' comments, reinforcing the conceptual connections they made. In doing so, they had opportunities to develop the scientific language and vocabulary necessary to continue to construct their knowledge of the states of matter.

In each instructional context, the teachers took up, or sanctioned, what literacies counted during integrated science-literacy instruction. As these excerpts illustrate, what constituted science was dramatically shaped by the teachers' different instructional uses of texts. In PS.2, the teacher's fragmented focus on accurate word reading and word knowledge demonstrated that science-related texts were used as a context for developing the "basic skills" of reading. In contrast, in PS.4, the teacher and students focused on understanding texts' ideas and using words and scientific language as tools to construct conceptual understandings related to science.

\section{Students' Participation in Integration of Science Learning}

Analysis of interactions in each classroom indicated that students' participation in integrated science-literacy instruction offered contrasting opportunities for science learning. In PS.2, students were required to find and remember science facts. Although they were sometimes allowed to display individual prior knowledge, this knowledge was rarely taken up or used to produce new understanding of science concepts. However, in PS.4, students' prior knowledge was taken up as part of the collaborative inquiry to produce knowledge.

\section{PS.2: Knowledge Consumers}

In PS.2, students worked to answer teacher-directed questions while reading science-related texts. Their participation included reading and recalling facts. The focus on the consumption of knowledge from texts encouraged views of science as a static collection of preexisting facts.

An excerpt from Ms. Burkhart's guided reading lesson illustrates her focus on students' knowledge consumption. The teacher guides discussion of a book about harvesting maple syrup:

Ms. Burkhart: What is dripping in this bucket? Remember what that's called?

Angel: Maple syrup

Ms. Burkhart: And what do they make maple syrup from? Go back to page 2 .

Sophia: The tree

Ms. Burkhart: Shh. Turn to page 2.

Daniel: Maple tree

Ms. Burkhart: Turn to page 2.

Daniel: That good?

Ms. Burkhart: Look at the tree. Read at the bottom quietly to yourself in your whisper voice. 
Alex: Aw man. Now we got to... [inaudible]

Ms. Burkhart: The answer is the very first sentence. What is dripping?

Sophia: Maple, maple, maple tree.

Ms. Burkhart: A tree is dripping into the bucket?

Students: [talking over one another] No, not the tree... The maple is... Maple... A lot of syrup.

Ms. Burkhart: Let's read it together. Ready? Put your finger on the first word.

Ms. Burkhart led students on a fact-finding mission in the science-related text. Students located and recalled texts' words. The teacher missed opportunities for connecting to students' prior knowledge to develop their understanding of, for example, the sap in maple trees. The lesson encouraged a view of science as a process of acquiring preexisting knowledge of the world through words and illustrations in texts.

\section{PS.4: Producers of Knowledge}

In PS.4, students engaged in collaborative inquiry and constructed new understandings about scientific concepts. The teacher's focus on students' production of knowledge that was new to them encouraged views of science as a process of discovering new insights about the world. Two excerpts from Ms. Eldridge's whole-group lessons illustrate students' knowledge production.

In the first excerpt from fieldnotes, Ms. Eldridge prepared students to make observations and construct understanding about properties of liquid during inquiry stations. These stations were a regular part of the daily routine in the afternoon, but as mentioned in the interview, the schedule was flexible, so science could be integrated throughout the day. On this day, the inquiry stations were conducted during her literacy instruction time:

Teacher reminds students that they are scientists all of the time, not just during science. She tells them that they're going to explore liquids today. She shows them five transparent jars containing different liquids. Five stations each with the same five jars.

Teacher says, "Pick up the container, observe, and find out everything you can about the liquid." Teacher reviews using senses to observe. Students have group roles and use the "Getter" role today. Teacher calls the Getter, names the people in their group, and tells them which table to go to.

Students manipulate the jars to explore the liquids. Teacher introduces ramps and goes to each group to demonstrate how to use the ramp to further explore how the liquid moves and the differences in speed as each jar rolls down the ramp. Students use many adjectives and adverbs as they describe the different liquids and how they move.

Students reassemble on the carpet to discuss their observations. Teacher tells students that they will do another lesson where they will be able to try to identify the contents of each jar. Today they are just talking about their observations about the liquid. Teacher writes on chart paper as the students talk about their observations. She asks many questions, i.e., "Why do you think some of the liquids moved fast and some moved slowly?" One student used the term viscose! The students talked about the particles being heavy or moving slowly, thick, etc.

In the excerpt, students made and discussed observations about properties of liquids. Ms. Eldridge took up their descriptions and wrote them on the chart. As this lesson illustrates, students in PS.4 had ongoing opportunities to participate in collaborative science inquiry and engage in the process of constructing new knowledge about science. 
In the second excerpt, students had opportunities to participate in the development of a shared understanding of how to access informational text. As Ms. Eldridge introduced the lesson, she chose a book from the basket in front of her and drew attention to the table of contents:

Ms. Eldridge: ....But it doesn't look like normal like the stories that are like "Once upon a time..." or "Once there was a..." It just doesn't look like that. I see lots of hands going, like it's going to fly off your body if you don't tell me; Susan, tell me what you wanna say.

Susan: It's a table of contents.

Ms. Eldridge: A table of contents! I love tables because we have one at home and I put my breakfast cereal...

Keith: Not that kind of table!

Ms. Eldridge: Not that kind of table? What does a table of contents even mean, Keith?

Keith: A table of contents is like when you get to know the chapters so like if there's a chapter called babies you look to see what number is next to it and you look to see it's on that page.

Ms. Eldridge: Eva?

Eva: Um, a table of contents is-it has everything in the book listed down that you want to know. And you see about the penguins and you see what number it's on and if you wanna learn about that thing you go to the pages and you'll learn about that.

Ms. Eldridge: So what I hear some of you saying is that a table of contents has page numbers and things the author wants you to know. So this one's about penguins and the author has all of these chapters or sections of the book listed that the author wants you to know.

In the excerpt, Ms. Eldridge provoked students' thinking to invite them to share what they knew about a table of contents. She publicized the student's extended explanation, making it part of the ongoing inquiry. Students participated in the inquiry process as experts helping one another to develop new knowledge about how to access the information they wanted to know in these kinds of texts.

In summary, students in both classrooms attempted to make connections and discoveries as they read science-related texts, but the instructional contexts supported their participation in different ways. In PS.2, the teacher encouraged student participation reflecting a passive view of knowledge consumption, whereas, in PS.4, student responses were taken up by the teacher and valued as part of the collaborative process of producing new knowledge.

\section{Discussion}

The current study extends prior research by raising concerns about the potential for integration to offer equitable science learning opportunities for all first-grade students. Researchers have argued that integrated science-literacy instruction can address time constraints and inequities in science instruction, provide opportunities to include informational text in daily instruction, and support primary students' science and literacy development (Girod \& Twyman, 2009; Jones \& Swanson, 2009; Mantzicopoulos et al., 2009; Vitale \& Romance, 2012).

Yet, our findings suggest that offering equitable science learning opportunities during time set aside for literacy in the absence of researchers' direct intervention may be more difficult than previous research implies. How teachers and students use the time and texts may contribute to what knowledge, skills, and meanings are available to students as they create science identity kits. Ultimately, students' opportunities for science learning may be constrained or supported by what and whose literacies are sanctioned within particular instructional contexts. These differences may lead to inequities that limit low-SES students' opportunities. 


\section{Instructional Contexts Constraining Opportunities for Science Learning}

In the instructional context of PS.2, students had few opportunities to talk, to think, and to act like scientists, potentially limiting future "access to social goods (money, power, status)" in scientific communities (Gee, 1991, p. 5; Wright \& Gotwals, 2017). Knowledge and knowing existed in texts, and the teacher monitored and evaluated students' attempts to read words and recall facts. Students were positioned as passive receivers of preexisting knowledge in texts. Their prior knowledge was not leveraged as a resource for constructing meaning.

According to Ms. Burkhart, the pressure to teach "the basics" of reading and math led to emphasizing what she labeled "easily scorable" literacies. When students engaged in literacies outside this valued "norm" by attempting a collaborative, inquiry approach to meaning-making, their attempts were ignored. As Ives (2011) pointed out, "Many of the literacies students possess go unnoticed or untapped in schools. In some cases, these literacies are not seen or valued because they are not viewed as appropriate or relevant in relation to officially sanctioned, school-based literacies" (p. 250).

Ms. Burkhart's spotlight on words rendered students' attempts to connect the science to more meaningful concepts irrelevant or off-task. The literacies that counted in this instructional context excluded science as a meaning-making process. Students' lack of opportunities to participate in hands-on inquiry with an ongoing, intentional focus on the science standards reflected, not just missed opportunities for future achievement, but also a failure to support students' participation as capable inquirers and producers of science knowledge.

\section{Instructional Contexts Supporting Opportunities for Science Learning}

In contrast, the instructional context in PS.4 supported students' opportunities for science learning. Students used prior knowledge, science-related texts, and hands-on inquiry as to jointly construct understanding of science concepts (Pappas et al., 2012). Students participated as capable inquirers in an active meaning-making community, and the fluid boundaries of science and literacy provided multiple opportunities for students to use literacies related to science inquiry.

Ms. Eldridge, who had reported experiencing more freedom to develop the science curriculum with her colleagues, emphasized the college-ready standards and a love for learning in determining what to teach. She used, and encouraged students to use, science-related texts as a tool to develop conceptual understandings related to science, but reading and discussion of the texts did not replace hands-on inquiry. Also, Ms. Eldridge took up and highlighted students' knowledge. Most importantly, she communicated to students through her words, the fluid schedule, and her focus on science as a collaborative inquiry process that "we are scientists all the time-not just in science."

\section{Contrasting Instructional Contexts in PS.2 and PS.4}

Given that these two classrooms existed within the same urban school district, one might expect similar opportunities for students' science learning during time set aside for literacy. However, striking inequities between the instructional contexts in the higher and low-SES school deserve further attention. During our observations, students in PS.2 had no opportunities to experience hands-on inquiry in science, and their reading of science-related texts was structured by the teacher to focus on words and facts. The science-literacy instruction reflected deficit assumptions about students as passive receivers of knowledge (Mangiante, 2018). This instructional context contrasted with that in PS.4, which offered frequent opportunities for students to think, to talk, and to act like scientists through ongoing hands-on and text-based inquiry and discussions of science-related texts. PS.2, which served a greater number of students of color and students living in poverty, provided an impoverished instructional context for students to develop new conceptual understandings related to 
science. This context constrained students' opportunities to shape identity kits through thinking, talking, and acting like scientists. The contrasting cases suggest that, unless the instructional contexts in urban schools are taken into account, integration of science during time set aside for literacy may exacerbate inequities in primary students' science development, motivation, and achievement.

\section{Implications}

This study suggests that a shift in policy and perspectives at the district and state levels is needed. Assumptions about how teachers integrate science during time set aside for literacy, particularly in low-SES schools, may obscure challenges they face as they try to enact more equitable and rigorous instruction. As this study shows, including more science-related text in the classroom did not determine students' opportunities for science learning. Instead, teachers directed students' engagement and participation in the reading of these science-related texts in consequential ways. As Ford (2004) argued, "It is the manner in which these books are used that makes the informational books worthwhile tools for inquiry" (p. 286). To help teachers leverage opportunities for students' literacy and science development, our findings suggest the need for more context-specific professional development on teachers' uses of science-related texts in urban primary-grade classrooms.

Also, the influence of state and district accountability systems on particular instructional contexts during integrated science-literacy instruction in urban, primary schools requires greater attention. These systems have power to influence what and whose literacies count during time set aside for literacy instruction and may differentially affect students in higher and low-SES schools (e.g., Au, 2011; Dooley \& Assaf, 2009; Hoffman, Assaf, \& Paris, 2001). In PS.2, current policies related to highstakes testing shaped what Ms. Burkhart valued and taught. Research continues to document this trend (Dooley \& Assaf, 2009; Maloch et al., 2013; Moon, Callahan, \& Tomlinson, 2003), and, until the inequitable consequences of these policies are more fully addressed, change will be slow, at best.

Finally, teachers and administrators need more context-specific supports to address factors embedded in particular instructional contexts, such as high-stakes testing pressure and deficit perspectives of students (Comber \& Kamler, 2004). Ms. Burkhart and others in low-SES schools have attributed their focus on teaching "the basics" to pressure from high-stakes testing. However, well before the passage of NCLB, researchers documented trends in which teachers in low-SES schools included fragmented instruction focused on isolated facts and teaching of "the basics" (Anyon, 1981). It may be that high-stakes testing policies simply serve to reinforce the enactment of deficit views, which continue to limit equitable science and literacy instruction for children living in poverty (Keefer, 2017). In making comparisons through a cross-case analysis, we do not suggest that teaching science and integrated science-literacy instruction in the same way across contexts is a more equitable solution. Instead, teaching in ways that are supported by research and rooted in responsive and culturally sustaining pedagogy will help ensure that all children benefit from learning science in the earliest grades (Bousselot, 2018; National Research Council, 2013; Paris \& Alim, 2014). Context-specific support requires working with teachers to help them better understand the communities and students they serve. Without this, and even with extensive professional development, teachers will likely continue to layer new practices on top of old beliefs and assumptions resulting in only surface-level changes in instruction (Kragler, Martin, \& Kroeger, 2008; Maloch et al., 2013; Martin \& Kragler, 2009).

\section{Conclusion}

Researchers have argued that integration of science during time set aside for literacy may hold potential for making time for science in urban schools and may lead to students' development in literacy and science (e.g., Lee et al., 2005). But this study of two first-grade teachers' science-literacy 
instruction illustrates that the generalized claim, "We integrate science into literacy instruction," may actually mask students' unequal opportunities for science learning. To realize the potential of integrated science-literacy instruction and safeguard against further inequities, we encourage continued research, policy initiatives, and professional development that attend to the network of factors embedded in instructional contexts, shaping what and whose literacies are valued and taught.

\section{References}

American Psychological Association. (2019, March 22). Ethnic and racial minorities and socioeconomic status. Retrieved from https://www.apa.org/pi/ses/resources/publications/minorities

Anyon, J. (1981). Social class and school knowledge. Curriculum Inquiry, 11, 3-42. doi:10.1080/03626784.1981.11075236

$\mathrm{Au}, \mathrm{W}$. (2011). Teaching under the new Taylorism: High-stakes testing and the standardization of the 21st century curriculum. Journal of Curriculum Studies, 43, 25-45. doi:10.1080/00220272.2010.521261

Barton, A. C., \& Yang, K. (2000). The culture of power and science education: Learning from Miguel. Journal of Research in Science Teaching, 37, 871-889. doi:10.1002/10982736(200010)37:8<871::AID-TEA7>3.0.CO;2-9

Barton, D. (2007). Literacy: An introduction to the ecology of written language. Malden, MA: Blackwell.

Bloome, D., Carter, S., Christian, B., Madrid, S., Otto, S., Shuart-Faris, N., \& Smith, M. (2008). On discourse analysis in classrooms: Approaches to language and literacy research. New York: Teachers College Press.

Brantlinger, E. (2003). Dividing classes: How the middle class negotiates and rationalizes school advantage. New York: Routledge.

Bousselot, T. E. (2018). Shifting the focus to science in the early elementary years: An examination of science achievement growth in grades $K-2$ using a nationally representative dataset (Doctoral dissertation). Retrieved from ProQuest. (UMI No. ED587861)

Casey, J. E., Mireles, S. V., Viloria, M. L., \& Garza, E. (2018) Literacy and arts integration in science: Engaging English language learners in a lesson on mixtures and solutions. Texas Journal of Literacy Education, 6, 51-69.

Cazden, C. B. (2001). Classroom discourse: The language of teaching and learning. Portsmouth, NH: Heinemann.

Charmaz, K. (2006). Constructing grounded theory: A practical guide through qualitative analysis. Thousand Oaks, CA: Sage.

Cervetti, G. N., Barber, J., Dorph, R., Pearson, P. D., \& Goldschmidt, P. G. (2012). The impact of an integrated approach to science and literacy in elementary school classrooms. Journal of Research in Science Teaching, 49, 631-658. doi:10.1002/tea.21015

Cervetti, G. N., Pearson, P. D., Bravo, M. A., \& Barber, J. (2005). Reading and writing in the service of inquiry-based science: Regents of the University of California. Retrieved from http://www.seedsofscience.org/PDFs/ScienceLiteracy.pdf

Comber, B., \& Kamler, B. (2004). Getting out of deficit: Pedagogies of reconnection. Teaching Education, 15, 293-310. doi:10.1080/1047621042000257225 
Curran, F. C. (2017). Income-based disparities in early elementary school science achievement. The Elementary School Journal, 118, 207-231. Retrieved from https://doi.org/10.1086/694218

Delpit, L. D. (1988). The silenced dialogue: Power and pedagogy in educating other people's children. Harvard Educational Review, 58, 280-298. doi:10.17763/haer.58.3.c43481778r528qw4

Diamond, J. B., \& Spillane, S. P. (2004). High-stakes accountability in urban elementary schools: Challenging or reproducing inequality? Teachers College Record, 106, 1145-1176. doi:10.1111/j.1467-9620.2004.00375.x

Dickinson, V. L., \& Young, T. A. (1998). Elementary science and language arts: Should we blur the boundaries? School Science and Mathematics, 98, 334-339. doi:10.1111/j.19498594.1998.tb17429.x

Dooley, C. M., \& Assaf, L. C. (2009). Contexts matter: Two teachers' language arts instruction in this high-stakes era. Journal of Literacy Research, 41, 354-391. doi:10.12691/education-2-8-18

Douville, P., Pugalee, D. K., \& Wallace, J. D. (2003). Examining instructional practices of elementary science teachers for mathematics and literacy integration. School Science and Mathematics, 103, 388-396. doi:10.1111/j.1949-8594.2003.tb18124.x

Dudley-Marling, C. (2015). The resilience of deficit thinking. Journal of Teaching and Learning, 10, 1-12. doi:10.22329/JTL.V10I1.4171

Duke, N. K. (2000a). 3.6 minutes per day: The scarcity of informational texts in first grade. Reading Research Quarterly, 35, 202-224. doi:10.1598/RRQ.35.2.1

Duke, N. K. (2000b). For the rich it's richer: Print experiences and environments offered to children in very low and very high-socioeconomic status first-grade classrooms. American Educational Research Journal, 37, 441-478. doi:10.3102/00028312037002441

Ehri, L. C., \& McCormick, S. (2013). Phases of word learning: Implications of instruction with delayed and disabled readers. In D. E. Alvermann, N. J. Unrau, \& R. B. Ruddell (Eds.), Theoretical models and processes of reading (6th ed., pp. 339-361). Newark, DE: International Reading Association.

Erickson, F. (2004). Talk and social theory: Ecologies of speaking and listening in everyday life. Malden, MA: Polity.

Fang, Z., \& Wei, Y. (2010). Improving middle school students' science literacy through reading infusion. The Journal of Educational Research, 103, 262-273. doi:10.1080/00220670903383051

Flick, H. (2009). An introduction to qualitative research. London, United Kingdom: Sage.

Ford, D. J. (2004). Highly recommended trade books: Can they be used in inquiry science? In W. Saul (Ed.), Crossing borders in literacy and science instruction: Perspectives on theory and practice (pp. 277-290). Newark, DE: International Reading Association.

Gee, J. P. (1991). What is literacy? In C. Mitchell \& K. Weiler (Eds.), Rewriting literacy: Culture and the discourse of the other (pp. 3-11). New York, NY: Bergin \& Garvey.

Gee, J. P. (2001). Reading as situated language: A sociocognitive perspective. Journal of Adolescent \& Adult Literacy, 44, 714-725. doi:10.1598/JAAL.44.8.3

Gee, J. P. (2004). Language in the science classroom: Academic social languages as the heart of school-based literacy. In E. W. Saul (Ed.), Crossing borders in literacy and science instruction: Perspectives on theory and practice (pp. 19-37). Newark, DE: International Reading Association. 
Girod, M., \& Twyman, T. (2009). Comparing the added value of blended science and literacy curricula to inquiry-based science curricula in two 2nd-grade classrooms. Journal of Elementary Science, 21, 13-32. doi:10.1007/BF03174720

Gorski, P. C. (2008). Peddling poverty for profit: Elements of oppression in Ruby Payne's framework. Equity \& Excellence in Education, 41, 130-148. doi:10.1080/10665680701761854

Hayes, K. N. (2015). Equity in elementary science education: A study of institutional and policy factors (Doctoral dissertation). Retrieved from ProQuest Information \& Learning. (UMI No. AAI3637843)

Hoffman, J. V., Assaf, L. C., Paris, S. G. (2001). High-stakes testing in reading: Today in Texas, tomorrow? Reading Teacher, 54, 482-492. Retrieved from https://ila.onlinelibrary.wiley.com/journal/19362714/

Hong, H., Moran, R. M., Jennings, L., Robertson, L., \& Fisher, S. (2019). Discourse of integrating science and literacy. In C. Tai, R. M. R. Moran, L. Robertson, K. Keith, \& H. Hong (Eds.), Handbook of research on science literacy integration in classroom environments (pp. 12-26). Hershey, PA: IGI Global. doi:10.4018/978-1-5225-6364-8

Howes, E. V., Lim, M., \& Campos, J. (2008). Journeys into inquiry-based elementary science: Literacy practices, questioning, and empirical study. Science Education, 93, 189-217. doi:10.1002/sce.20297

Ippolito, J. C., Condie, C., Dobbs, C. L., Charner-Laird, M. \& Blanchette, J. (2017). Planting seeds: To grow science disciplinary literacy skills we must layer basic and intermediate literacy skills across K-12. Massachusetts Reading Primer, 45, 14-23. doi:10.2505/4/sc18_056_04_91

Ives, D. (2011). Spotting foolbirds: Literacies hiding in plain sight in an urban English language arts classroom. Journal of Literacy Research, 43, 250-274. doi:10.1177/1086296X11413721

Jones, R., \& Swanson, E. (2009). Understanding elementary teachers' use of science teaching time: Lessons from the Big Sky Science Partnership. Journal of Mathematics and Science: Collaborative Explorations, 11, 163-192. Retrieved from https://math.vcu.edu/about/k-12outreach/collaborative-explorations/

Keefer, N. (2017). The presence of deficit thinking among social studies educators. Journal of Social Studies Educational Research, 8, 50-75.

Keys, C. W., \& Bryan, L. A. (2001). Co-constructing inquiry-based science with teachers: Essential research for lasting reform. Journal of Research in Science Teaching, 38, 631-645. doi:10.1002/tea.1023

Kragler, S., Martin, L., \& Kroeger, D. (2008). Money down the drain: Mandated professional development. Journal of School Leadership, 18, 528-550.

Kucsera, J. V., Siegel-Hawley, G., \& Orfield, G. (2014). Are we segregated and satisfied? Segregation and inequality in Southern California schools. Urban Education, 50, 535-571. doi:10.1177/0042085914522499

Ladson-Billings, G. (2014). The pedagogy of poverty: Big lies about poor children. In P. C. Gorski \& K. Zenkov (Eds.), The big lies of school reform: Finding better solutions for the future of public education (pp. 7-16). New York, NY: Routledge.

Lakoff, R. T. (2015). Nine ways of looking at apologies: The necessity for interdisciplinary theory and method in discourse analysis. In D. Tannen, H. E. Hamilton, \& D. Schiffrin (Eds.), The handbook of discourse analysis (Vol. 1, 2nd ed., pp. 293-308). West Sussex, United Kingdom: John Wiley \& Sons. 
Lee, O., Deaktor, R. A., Hart, J. E., Cuevas, P., \& Enders, C. (2005). An instructional intervention's impact on the science and literacy achievement of culturally and linguistically diverse elementary students. Journal of Research in Science Teaching, 42, 857-887. doi:10.1002/tea.20071

Lindquist, W., \& Neal, R. A. (2018). Promoting equity, inclusion and accessibility in literacy-rich science learning environments. In M. Koomen, S. Kahn, C. L. Atchison, \& T. A. Wild (Eds.), Towards inclusion of all learners through science teacher education (pp. 241-249). Leiden, The Netherlands: Brill. doi:10.1163/9789004368422_026

Maloch, B., Worthy, J., Hampton, A., Jordan, M., Hungerford, H., \& Semingson, P. (2013). Portraits of practice: A cross-case analysis of two first grade teachers and their grouping practice. Research in the Teaching of English, 47, 277-312. Retrieved from http://www2.ncte.org/resources/journals/research-in-the-teaching-of-english/

Maltese, A. V., \& Tai, R. H. (2010). Eyeballs in the fridge: Sources of early interest in science. International Journal of Science Education, 32, 669-685. doi:10.1080/09500690902792385

Mangiante, E. S. (2018). Planning for reform-based science: Case studies of two urban elementary teachers. Research in Science Education, 48, 207-232. doi:10.1007/s11165-016-9566-2

Mantzicopoulos, P., Patrick, H. \& Samarapungavan, A. (2009). The scientific literacy project. Retrieved from http://www.purduescientificliteracyproject.org

Marshall, S. L. (2018). Elementary principal networks: Sensemaking of science education policy postNCLB (Doctoral dissertation). Retrieved from ProQuest. (UMI No. ED587968)

Martin, L. E., \& Kragler, S. (2009). School reform: An inside view of professional development. In F. Falk-Ross, S. Szabo, M. B. Sampson, M. M. Foote (Eds.), Literacy issues during changing times: A call to action (Vol. 30, pp. 234-247). Arlington, TX: College Reading Association. Retrieved from http://files.eric.ed.gov/fulltext/ED507687.pdf?ref= driverlayer.com/web\# page $=247$

Marzollo, J. (1996). I'm a seed. New York, NY: Scholastic.

Matuk, C., Hurwich, T., Spiegel, A., \& Diamond, J. (2019). How do teachers use comics to promote engagement, equity, and diversity in science classrooms? Research in Science Education. Advance online publication. doi:10.1007/s11165-018-9814-8

Merriam, S. B., \& Tisdell, E. J. (2016). Qualitative research: A guide to design and implementation (4th ed.). San Francisco, CA: Jossey-Bass.

Merritt, E. G., Chiu, J., Peters-Burton, E., \& Bell, R. (2018). Teachers' integration of scientific and engineering practices in primary classrooms. Research in Science Education, 48, 1321-1337. doi:10.1007/s11165-016-9604-0

Moon, T. R., Callahan, C. M., \& Tomlinson, C. A. (2003). Effects of state testing programs on elementary schools with high concentrations of student poverty-Good news or bad news? Current Issues in Education, 6, 1-22. Retrieved from https://cie.asu.edu/ojs/index.php/cieatasu/article/view/1683

Morgan, P. L., Farkas, G., Hillemeier, M. M., \& Maczuga, S. (2016). Science achievement gaps begin very early, persist, and are largely explained by modifiable factors. Educational Researcher, 45, 18-35. doi:10.3102/0013189X16633182

Nagy, W., \& Townsend, D. (2012). Words as tools: Learning academic vocabulary as language acquisition. Reading Research Quarterly, 47, 91-108. doi:10.1002/RRQ.011

National Research Council. (2012). A framework for K-12 science education: Practices, crosscutting concepts, and core ideas. Washington, DC: National Academic Press. 
National Research Council. (2013). Next Generation Science Standards: For states, by states. Washington, DC: The National Academies Press. doi:10.17226/18290

Nelson, S. D., \& Norton-Meier, L. (2009). Singing in science: Writing and recording student lyrics to express learning. Journal for Learning through the Arts, 5. doi:10.21977/D95110029

No Child Left Behind Act of 2001, P.L. 107-110, 20 U.S.C. $§ 6319$ (2002).

Nollmeyer, G. E., Kelting-Gibson, L., \& Graves, C. J. (2016). Mapping the domain of subject area integration: Elementary educators' descriptions and practices. International Journal of Learning, Teaching and Educational Research, 15, 1-27.

Nystrand, M. (1997). Opening dialogue: Understanding the dynamics of language and learning in the English classroom. New York, NY: Teachers College Press.

Odegaard, M., Haug, B., Mork, S., \& Sorvik, G. O. (2015). Budding science and literacy: A classroom video study of the challenges and support in an integrated inquiry and literacy teaching model. Social and Behavioral Sciences, 167, 274-278. doi:10.1016/j.sbspro.2014.12.674

Pappas, C. C., Varelas, M., Kokkino Patton, S., Ye, L. \& Ortiz, I. (2012). Dialogic strategies in readalouds of English-language information books in a second-grade bilingual classroom. Theory Into Practice, 51, 263-272. doi:10.1080/00405841.2012.726054

Paris, D. \& Alim, H. S. (2014). What are we seeking to sustain through culturally sustaining pedagogy? A loving critique forward. Harvard Educational Review, 84, 84-100. Retrieved from https://doi.org/10.17763/haer.84.1.9821873k2ht16m77

Pearson, P. D., Moje, E., \& Greenleaf, C. (2010). Literacy and science: Each in the service of the other. Science, 328, 459-463. doi:10.1126/science.1182595

Pitts, W. (2011). Potentialities beyond deficit perspectives: Globalization, culture and urban science education in the Bronx. Cultural Studies of Science Education, 6, 89-112. doi:10.1007/s11422-010-9301-7

Poldberg, M. M., Trainin, G., \& Andrzejczak, N. (2013). Rocking your writing program: Integration of visual art, language arts, \& science. Journal for Learning through the Arts, 9, 1-22.

Pressley, M., \& Allington, R. L. (2015). Reading instruction that works: The case for balanced teaching (4th ed.). New York, NY: Guildford.

Purcell-Gates, V., Duke, N. K., \& Martineau, J. A. (2007). Learning to read and write genre-specific text: Roles of authentic experience and explicit teaching. Reading Research Quarterly, 42, 845. doi:10.1598/RRQ.42.1.1

Robertson, L., \& Moran, R. M. (2019). Teacher perspectives on science and literacy integration. In C. Tai, R. M. R. Moran, L. Robertson, K. Keith, \& H. Hong (Eds.), Handbook of research on science literacy integration in classroom environments (pp. 322-336). Hershey, PA: IGI Global. doi:10.4018/978-1-5225-6364-8

Sang, Y. (2017). Expanded territories of "literacy": New literacies and multiliteracies. Journal of Education and Practice, 8, 16-19. Retrieved from https://iiste.org/Journals/index.php/JEP/article/view/36029

Savin-Baden, M., \& Major, C. H. (2013). Qualitative research: The essential guide to theory and practice. New York, NY: Routledge.

Shanahan, C., \& Shanahan, T. (2014). The implications of disciplinary literacy. Journal of Adolescent \& Adult Literacy, 57, 628-631. doi:10.1002/jaal.297

Smith, P. S., Trygstad, P. J., \& Banilower, E. R. (2016). Widening the gap: Unequal distribution of resources for K-12 science instruction. Education Policy Analysis Archives, 24. doi:10.14507/epaa.v24.2207 
Sørvik, G. O., Blikstad-Balas, M., \& Ødegaard, M. (2014). “Do books like these have authors?" New roles for text and new demands on students in integrated science-literacy instruction. Science Education, 99, 39-69. doi:10.1002/sce.21143

Southerland, S., Gallard, A., \& Callihan, L. (2011). Examining teachers' hurdles to "science for all." International Journal of Science Education, 33, 2183-2213. doi:10.1080/09500693.2010.530698

Sunderman, G. L. (Ed.). (2008). Holding NCLB accountable: Achieving accountability, equity, and school reform. Thousand Oaks, CA: Corwin Press.

Tolbert, S., Stoddart, T., Lyon, E. G., \& Solis, J. (2014). The Next Generation Science Standards, Common Core State Standards, and English learners: Using the SSTELLA framework to prepare secondary science teachers. Issues in Teacher Education, 23, 65-90. Retrieved from https://www.itejournal.org/index.html

Vitale, M. R. \& Romance, N. R. (2012). Using in-depth science instruction to accelerate student achievement in science and reading comprehension in Grades 1-2. International Journal of Science and Mathematics Education, 10, 457-472. doi:10.1007/s10763-011-9326-8

Wenger, E. (1998). Communities of practice: Learning, meaning, and identity. New York, NY: Cambridge University Press.

Wright, T. S., \& Gotwals, A. W. (2017). Supporting kindergartners' science talk in the context of an integrated science and disciplinary literacy curriculum. The Elementary School Journal, 117, 513-537. doi: 10.1086/690273

Xu, J., Coats, T., \& Davidson, L. (2012). Promoting student interest in science: The perspectives of exemplary African American teachers. American Educational Research Journal, 49, 124154. doi:10.3102/0002831211426200

The Journal of Educational Research and Practice provides a forum for studies and dialogue that allows readers to better develop social change in the field of education and learning. Journal content may focus on educational issues of all ages and in all settings. It also presents peer-reviewed commentaries, book reviews, interviews of prominent individuals, and additional content. The objectives: We publish research and related content that examines current relevant educational issues and processes aimed at presenting readers with knowledge and showing how that knowledge can be used to impact social change in educational or learning environments. Additional content provides an opportunity for scholarly and professional dialogue regarding that content's usefulness in expanding the body of scholarly knowledge and increasing readers' effectiveness as educators. The journal also focuses on facilitating the activities of both researcher-practitioners and practitioner-researchers, providing optimal opportunities for interdisciplinary and collaborative thought through blogging and other communications.

Walden University Publishing: http://www.publishing.waldenu.edu 